\title{
Erratum to: Herbiciding invasive reed: indirect effects on habitat conditions and snail-algal assemblages one year post-application
}

\author{
Christina L. Back • Joseph R. Holomuzki • \\ David M. Klarer · Robert S. Whyte
}

Published online: 24 April 2013

(C) Springer Science+Business Media Dordrecht 2013

\section{Erratum to: Wetlands Ecol Manage (2012) 20:419-431 \\ DOI 10.1007/s11273-012-9265-3}

We recently published an experimental study done in a Lake Erie coastal marsh in which $1520 \times 20$ m plots of invasive Phragmites australis (common reed) were treated with either a $30 \%$ solution of the glyphosate herbicide AquaNeat ${ }^{\circledR}$, a $5 \%$ solution of the imazapyrbased herbicide Habitat ${ }^{\circledR}$, or left herbicide-free ( $n=5$ for each treatment) (Back et al. 2012). Our goal was to assess the indirect effects of herbiciding on snail-algal linkages 1-year after herbiciding using maximum allowable concentrations. In error, a $30 \%$ AquaNeat ${ }^{\circledR}$ solution was applied with a backpack sprayer.

The online version of the original article can be found under doi:10.1007/s11273-012-9265-3.

\section{L. Back}

Department of Evolution, Ecology, and Organismal Biology, The Ohio State University, Columbus, $\mathrm{OH} 43212$, USA

Present Address:

C. L. Back

The McGraw-Hill Co., 8787 Orion Place, Columbus, OH 43240, USA
Such a concentration is $\sim 6$ times greater than the approved limit on the product label for this application method and should never be used in a management context. The error likely did not cause any health or environmental risks. AquaNeat ${ }^{\circledR}$ can be used at $33 \%$ solutions when wicking reed and at 50 to $100 \%$ solutions when treating woody vegetation. Regardless of concentration, the key to avoiding health risks is not to inhale the spray mist (stated on product label). Glyphosates have low acute toxicity, apparently lack carcinogenicity, are highly soluble in water, and are inactivated in water and soil by microbial degradation relatively quickly (USEPA 1993; Schuette 1998; Geisy et al. 2000). Water levels at our research site in Sheldon Marsh fluctuate $\sim 12 \mathrm{~cm}$ per day from early June to July from changing wind patterns and Lake Erie seiches (Back et al. 2012). So, water exchange facilitated dissipation/dilution of sprayed

D. M. Klarer

Ohio Department of Natural Resources, Old Woman Creek National Estuarine Research Reserve, Cleveland Road East, Huron, OH 44839, USA

R. S. Whyte

Department of Biological and Environmental Sciences, California University of Pennsylvania, California, PA 15419, USA

J. R. Holomuzki ( $\square)$

Department of Evolution, Ecology, and Organismal

Biology, The Ohio State University, Mansfield,

OH 44903, USA

e-mail: holomuzki.3@osu.edu 
material reaching the water during application (14 June 2007). Waters in Sheldon Marsh are not used as a drinking water source.

\section{References}

Back CL, Holomuzki JR, Klarer DM, Whyte RS (2012) Herbiciding invasive reed: indirect effects on habitat conditions and snail-algal assemblages one year postapplication. Wetlands Ecol Manage 20:419-431

Geisy JP, Dobson S, Solomon KR (2000) Ecotoxicological risk assessment for Roundup ${ }^{\circledR}$ herbicide. Rev Environ Contam Toxicol 167:35-120

Schuette J (1998) Environmental fate of glyphosate. Environmental Monitoring and Pest Management, Dept. Pesticide Regulation, Sacramento, CA

USEPA (1993) Reregistration eligibility decision. Office of Prevention, Pesticides, and Toxic Substances. EPA: 738-R93-014 